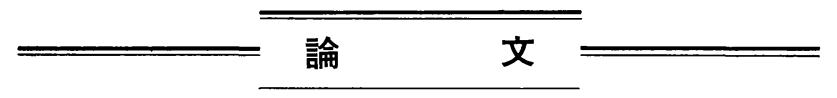

農業気象 $(J . A g r . M e t) \quad .35(1): 1-12,1979$

\title{
Studies on Photosynthesis and Primary Production of Rice Plants in Relation to Meteorological Environments.
}

\section{Gaseous diffusive resistances, photosynthesis and transpiration in the leaves} as influenced by atmospheric humidity, and air and soil temperatures.

\author{
Takeshi HORIE
}

\author{
(Division of Meteorology, National Institute of Agricultural Sciences,
Nishigahara 2-1, Kita-ku, Tokyo
}

\begin{abstract}
With the purpose to obtain necessary plant data for constructing a simulation model for photosynthesis and growth of rice plant, measurements were made on rice leaves with a leaf chamber method, of the diffusive resistances of stomata $\left(r_{s}\right)$ and mesophyll $\left(r_{M}\right)$ and also of rates of net photosynthesis $\left(P_{n}\right)$ and transpiration $(E)$ in relation to ambient humidity, air and soil temperatures.

Oscillation in $P_{n}, E$ and also in temperature difference between leaf and air was observed at relative humidity less than $40 \%$ at $30^{\circ} \mathrm{C}$, which was equivalent to $25 \mathrm{mb}$ in vapour pressure difference $(V D)$ between leaf and air. The period of the oscillation appeared to be 15 minutes and the amplitude increased with $V D$ increase. The oscillation was found to be caused by that of the stomata. At $V D$ less than $15 \mathrm{mb} r_{s}$ was constant, but above this $V D$ it increased almost proportionally to $V D$ increase, while $r_{M}$ was unaffected by $V D$. As a consequence, $P_{n}$ and $E$ both were suppressed at higher $V D$ to a considerable extent.

With the increase in leaf temperature at a constant relative humidity, $r_{s}$ seemingly increased. However, the apparent increase in $r_{s}$ with the temperature was attributable to the increase in $V D$ associated with the temperature increase, and $r_{s}$ corrected with $V D$ appeared to decrease with the temperature. It was found that $r_{M}$ decreases with the increase in temperature in negative exponential fashion. A treatment of $10^{\circ} \mathrm{C}$ soil temperature for 22 hours resulted in an increase in $r_{s}$ by $30-40 \%$ and a reduction in $P_{n}$ by $7-11 \%$ to those at $20^{\circ} \mathrm{C}$ soil temperature.

Based on these experimental evidences, a numerical evaluation was made for the interacting effects of the air temperature and the humidity on $P_{n}$ and $E$. It was suggested that the optimal temperature for $P_{n}$ may shift upwards with the increase in the humidity and that $P_{n}$ at the optimal temperature is higher the higher the humidity.
\end{abstract}

\section{Introduction}

This series of work has been initiated with the intention to develop a simulation model for rice plant, which may explain and predict the photosynthesis and the growth in relation to the meteorological environments. To obtain necessary data for constructing the model, gaseous diffusive properties of rice leaves in dependence of the

Read at The Annual Meeting, 25 May, 1978

Received 9 October, 1978. environments have been investigated at first, since very little is known in rice, the main crop in monsoon Asia, about the stomatal and the mesophyll diffusive resistances in relation to meteorological factors and since these resistances play a key role in the plant-environment interactions. In continuation of a previous report about the gaseous diffusive resistances of rice leaves in relation to wind velocity and radiation intensity (Horie, 1978), this report concerns the effects of atmospheric humidity and air and soil temperatures upon the 
diffusive resistances of the leaves.

The effects of atmospheric humidity and air temperature on the stomatal diffusive resistance to water vapour and $\mathrm{CO}_{2}$ transfer, and hence on the photosynthesis and the transpiration, appear to be still conflicting. For example, Lange et al. (1971), Schulze et al. (1972) and Aston (1976) reported that the stomatal resistance changed to a considerable extent with the change in the atmospheric humidity, while Barrs (1973) and Rawson and Begg (1977) reported no stomatal response to the humidity. As for temperature effect, Meidner and Mansfield (1968) reviewed literature thoroughly and reported that the temperature effects on stomatal aperture were also conflicting. They made an attempt to explain the seemingly conflicting temperature effects by introducing the $\mathrm{CO}_{2}$ factor in the leaf intercellular spaces.

The rice plants are grown in flooding water conditions in most growing period and hence the water environment, which gives the largest influence on the stomatal resistance, is greatly different from other crops, so that the stomatal responses to the environments are expected to be different from other crops. Ishihara et al. (1971 a and b) made measurements of degree of the stomatal aperture in rice leaves under field conditions with an infiltration method, and found that the stomatal aperture was affected to a marked degree with the humidity condition at the field. If the stomatal resistance is sensitive to the atmospheric humidity, then the conflicting temperature effects on the stomatal resistance might be explained, at least partly, from the humidity factor, because the saturation vapour pressure deficit in leaves is a function of temperature. Moreover, it would also be the case that the humidity condition affects the temperature-photosynthesis relationships.

To make the above mentioned points much clearer, measurements were made on rice leaves of the diffusive resistances of the stomata and the mesophyll and also of the rates of net photosynthesis and transpiration in relation to the humidity and air and soil temperatures. This paper describes the effects of the ambient humidity, air and soil temperatures on the stomatal and the mesophyll resistances and also on the rates of net photosynthesis and transpiration of rice leaves.

\section{Material and Methods}

Most measurements were made on a rice variety of "Nipponbare", a most popular rice cultivar in Japan. In the measurements of photosynthesistemperature relation, a rice cultivar "Reimei", a variety only raised at northern district of Japan, was also used for comparison. The growing conditions of these rice plants were same as have been described in a previous report (Horie, 1978).

Measurements of net photosynthesis and transpiration were made with the leaf chamber method on intact leaves of potted rice plants at the maximum tillering stage. The setup used for the simultaneous measurements of the net photosynthesis and the transpiration has already been described in the previous report. Namely, the setup allows the measurements under controlled conditions of air temperature, humidity and radiation intensity at any desired level. The rate of net photosynthesis or transpiration was determined by multipling the air flow rate through the chamber to the difference in $\mathrm{CO}_{2}$ concentration or in water vapour concentration between the inlet and outlet of the chamber. The $\mathrm{CO}_{2}$ concentration difference was measured with a differential type infrared $\mathrm{CO}_{2}$ analyser (Beckman, model 865) and the water vapour with a dew-point hygrometer (EG \& G, model 880). Average leaf temperature over the leaves in the chamber was measured with four pairs of copper-constantan thermocouples of 0.1 $\mathrm{mm}$ in diameter, which were stuck on the abaxial surfaces of the leaves.

Most measurements were made under a constant conditions of short-wave radiation intensity being $0.64 \mathrm{cal} \mathrm{cm}^{-2} \min ^{-1}$ ( $=0.28 \mathrm{cal} \mathrm{cm}^{-2} \mathrm{~min}^{-1}$ in PAR) and $\mathrm{CO}_{2}$ concentration in the chamber about 330 $\mathrm{ppm}$, with the exception of those for $\mathrm{CO}_{2}$ compensation points of photosynthesis. The $\mathrm{CO}_{2}$ compensation points were determined by measuring photosynthesis under different $\mathrm{CO}_{2}$ concentration in the chamber, including $\mathrm{CO}_{2}$-free air. The $\mathrm{CO}_{2}$ concentration was controlled at a given level by changing the mixing ratio of normal air and $\mathrm{CO}_{2}$-free air produced with soda lime. Soil temperature treatments were given by placing the pot in a temperature-controlled water bath. On each measurement, 6 or more leaves from different nodes and tillers of a plant were inserted into the 
chamber. Thus, the rates of net photosynthesis and transpiration gave averaged values over the leaves per plant.

The total diffusive resistance to water vapour transfer between the air and the intercellular spaces in the leaf was calculated from the following equation:

$r_{a}+r_{s}=\frac{2 \times 2.17 \times 10^{-4}}{E}\left\{\frac{e_{s}\left(T_{l}\right)}{273+T_{l}}-\frac{e_{a}}{273+T_{a}}\right\}$

in which $r_{a}+r_{s}$ is the total diffusive resistance in $\mathrm{sec} \mathrm{cm}^{-1} ; E$ the rate of transpiration in $\mathrm{gH}_{2} \mathrm{O} \mathrm{cm}^{-2}$ $\sec ^{-1} ; T_{l}$ and $T_{a}$ the leaf and the air temperatures in centigrade; $e_{s}\left(T_{l}\right)$ the saturation vapour pressure (mb) at $T_{l} ; e_{a}$ the vapour pressure in the air $(\mathrm{mb})$. The factor 2 accounts for an even stomatal distribution on both surfaces of the leaf. The boundary layer resistance $\left(r_{a}\right)$ on the leaves in the chamber, as determined with model rice leaves made of a filter paper, was shown to be given by the following equation (Horie, 1978):

$$
r_{a}=2.1 d^{1 / 2} U^{-1 / 2}
$$

where 2.1 is a proportional constant; $d$ the effective leaf length along the wind direction; $U$ the wind speed in $\mathrm{cm} \mathrm{sec}^{-1}$. By subtracting $r_{a}$ from the total diffusive resistance given by eq. (1), the stomatal diffusive resistance $r_{s}$ can be evaluated.

The mesophyll resistance $r_{M}$ was calculated by the following equation, which is derived from Holmgren, Jarvis and Jarvis (1965):

$$
r_{M}=\frac{C_{a}-\Gamma}{P_{n}}-\frac{r_{a c}+r_{s c}}{2}
$$

in which $C_{a}$ is the ambient $\mathrm{CO}_{2}$ concentration; $\Gamma$ the compensation $\mathrm{CO}_{2}$ concentration in photosynthesis; $P_{n}$ the rate of net photosynthesis; $r_{a c}$ and $r_{s c}$ the diffusive resistances to $\mathrm{CO}_{2}$ transfer at the boundary layer and at the stomata. $r_{a c}$ and $r_{s c}$ were calculated from those to water vapour transfer, as (Thom, 1968 and Jarvis, 1971):

and

$$
r_{a c}=r_{a}\left(\frac{D_{H}}{D_{C}}\right)^{2 / 3}
$$

$$
r_{s c}=r_{s}\left(\frac{D_{H}}{D_{C}}\right)
$$

where $D_{H}$ and $D_{C}$ are the molecular diffusivities of water vapour and carbondioxide, respectively. According to Slatyer and Jarvis (1966), 1.68 was adopted for the ratio $D_{H} / D_{C}$.
As has already been described in the previous report, the mesophyll resistance $r_{M}$, thus determined, is not purely physical resistance to $\mathrm{CO}_{2}$ transfer in the liquid phase in the mesophyll, but also inclusive of carboxylation resistance. For this reason, $r_{M}$ in this context has only a value of representing the relative degree of contribution of the residual processes, other than the purely physical $\mathrm{CO}_{2}$ transfer process in the air phase, to net photosynthetic rate.

\section{Results and Discussion}

\subsection{Influence of atmospheric humidity}

Fig. 1 shows changes with relative humidity in the rates of net photosynthesis $\left(P_{n}\right)$ and transpiration $(E)$, the diffusive resistances of stomata $\left(r_{s}\right)$ and mesophyll $\left(r_{M}\right)$, and also in the temperature difference between leaves and air $\left(T_{l}-T_{a}\right)$. Fig. 1 is derived from continuous measurements of $P_{n}$, $T_{l}$ and $T_{a}$, and discontinuous measurements of $E$ and $r_{s}$, when the humidity was progressively decreased from $80 \%$ to $23 \%$ and thereafter it was increased again up to $64 \%$. In general, the decrease in the humidity resulted in the increase in $E$ and the decrease in the leaf temperature. The mesophyll resistance was unaffected by the humidity treatments, while the stomatal resistance $r_{s}$ increased gradually with the decrease in the humidity from $60 \%$ downwards. The photosynthetic rate $P_{n}$ showed maximum rate at $80-60 \%$ relative humidity, and with the further reduction in the humidity it tended to decrease as $r_{s}$ increased.

In the humidity range from 40 to $80 \%$, small fluctuations may be appreciated in $P_{n}$ and also in $T_{l}-T_{a}$, but the fluctuations were not periodical and the amplitudes were small. For these reasons, the fluctuations observed at humidity range above $40 \%$ may not be regarded as the oscillation. With the further reduction in the humidity from $40 \%$ at $30^{\circ} \mathrm{C} T_{a}$ (=25 mb vapour pressure difference between leaf and air) downwards, the fluctuations became very periodical and the amplitudes of them larger. Moreover, a clear parallelism can be seen in the phase of the fluctuations of $P_{n}, T_{l}-T_{a}$, $E$ and also in $r_{s}$, although the latter two quantities were less frequently measured than the former two. Hence, the fluctuations observed at relative humidity below $40 \%$ may be regarded as the oscillations caused by the stomatal movements, as 


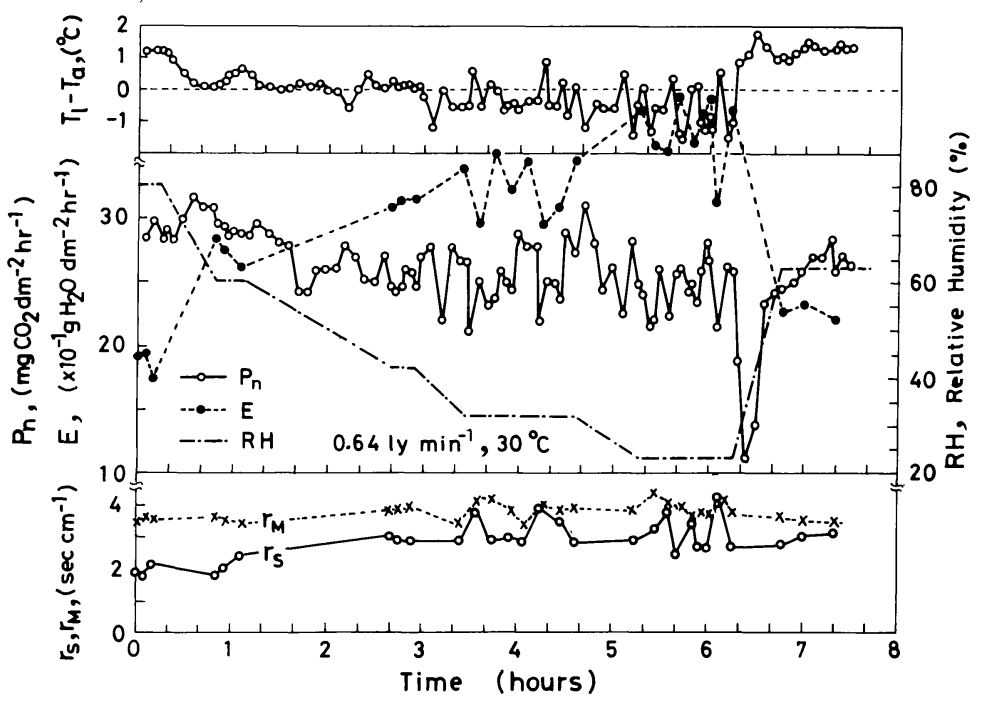

Fig. 1. Changes with relative humidity $(\mathrm{RH})$ in rates of net photosynthesis $\left(P_{n}\right)$ and transpiration $(E)$, diffusive resistances of stomata $\left(r_{s}\right)$ and mesophyll $\left(r_{M}\right)$, and temperature difference between leaf and air $\left(T_{l}-T_{a}\right)$ in rice leaves at $30^{\circ} \mathrm{C} T_{a}$.

was reported in many plant species under certain environmental conditions (Ehrler et al., 1965, and Shirazi and Stone, 1976).

Fig. 1 also shows that the period of the oscillations at $33 \%$ relative humidity was approximately same as that at $23 \%$ and about 15 minutes, while the amplitudes were larger at the lower humidity. The amplitudes in $T_{l}-T_{a}, P_{n}, E$ and in $r_{s}$ at $33 \%$ relative humidity were $0.5^{\circ} \mathrm{C}, 1.9 \mathrm{mgCO}_{2} \mathrm{dm}^{-2}$ $\mathrm{hr}^{-1}, 0.2 \mathrm{gH}_{2} \mathrm{O} \mathrm{dm}^{-2} \mathrm{hr}^{-1}$ and $0.34 \mathrm{sec} \mathrm{cm} \mathrm{cm}^{-1}$ respectively, while those at $23 \%$ relative humidity were $0.83^{\circ} \mathrm{C}, 2.3 \mathrm{mgCO}_{2} \mathrm{dm}^{-2} \mathrm{hr}^{-1}, 0.25 \mathrm{gH}_{2} \mathrm{O}$ $\mathrm{dm}^{-2} \mathrm{hr}^{-1}$ and $0.47 \mathrm{sec} \mathrm{cm}^{-1}$.

Since the oscillations, appeared at lower humidity, diminished with the subsequent increase in the humidity (Fig. 1), it is considered that the oscillation of the stomatal resistance was caused by the increased transpiration demand as imposed by lowering the humidity. With respect to the mechanism of the stomatal oscillation, two hypotheses were proporsed respectively by Stålfelt (1956) and Raschke (1965). Stålfelt's hypothesis is such that, under conditions of high transpiration demand, a water deficit develops in leaves, causing the stomatal closure, and then the reduction in transpiration follows, which in turn corrects the water deficit, and the stomatal opening occurs again. While the hypothesis by Raschke is that the stomata are operating as an oscillating regulator effecting a constant $\mathrm{CO}_{2}$ supply to the leaves. In Raschke's case, the period of the oscillation is of 5-6 minutes, while that caused by the water balance was reported to be 20-30 minutes (Ehrler et al., 1965; Meidner and Mansfield, 1968; Shirazi and Stone 1976). The period of the oscillation here observed with rice leaves was about 15 minutes, which value is much closer to the latter than the former. For this reason, the oscillation observed in the rice leaves under low humidity may be considered to be caused by the change in water status in the leaves. However, the possibility that $\mathrm{CO}_{2}$ is also involved in this process can not perfectly be denied, since it has been shown in a previous report with rice (Horie, 1978), that stomata may stabilize the $\mathrm{CO}_{2}$ concentration in the leaf intercellular spaces on a constant level over a wide range of the radiation intensity.

To analyse quantitatively the effect of the humidity on the stomatal resistance $\left(r_{s}\right)$, the transpiration rate $(E)$ and the net photosynthetic rate $\left(P_{n}\right)$, difference in water vapour pressure between leaf and air, or in another word the saturation vapour pressure deficit $(V D)$, was calculated for each case of the measurements, because $V D$ is more directly related to $E$ than the relative humidity. Moreover, data of $P_{n}, E, r_{s}$ and the mesophyll 
resistance $r_{M}$ at a given $V D$ condition were divided by the values of these quantities at $10 \mathrm{mb} V D$ for each series of the measurements, to give the relative effects of $V D$ on these quantities. The relative photosynthesis, transpiration, and stomatal and mesophyll resistances, thus determined, were plotted against the vapour pressure deficit $V D$ (Fig. 2).

As can be seen in Fig. 2, the stomatal resistance $r_{s}$ was constant until $V D$ reached about $15 \mathrm{mb}$, but thereafter it increased almost proportionally to $V D$, so that the value of $r_{s}$ at $30 \mathrm{mb} V D$ was almost twice of that at $10 \mathrm{mb} V D$. The transpiration rate $(E)$ at $30 \mathrm{mb} V D$ was about twice of that at $10 \mathrm{mb} V D$. If $r_{s}$ would not be affected by $V D$, this ratio should be threefold, and hence $34 \%$ reduction of $E$ resulted in with about twofold increase in $r_{s}$ as $V D$ increased from 10 to $30 \mathrm{mb}$. The net photosynthetic rate $\left(P_{n}\right)$ at $30 \mathrm{mb} V D$ was about $75 \%$ of that at $10 \mathrm{mb} V D$, and hence the degree of the reduction was about $25 \%$. This reduction ratio was smaller than that in $E$. This is because, not only the diffusive resistances of the stomata and the boundary layer, but also the mesophyll resistance $r_{M}$ is included in photo-

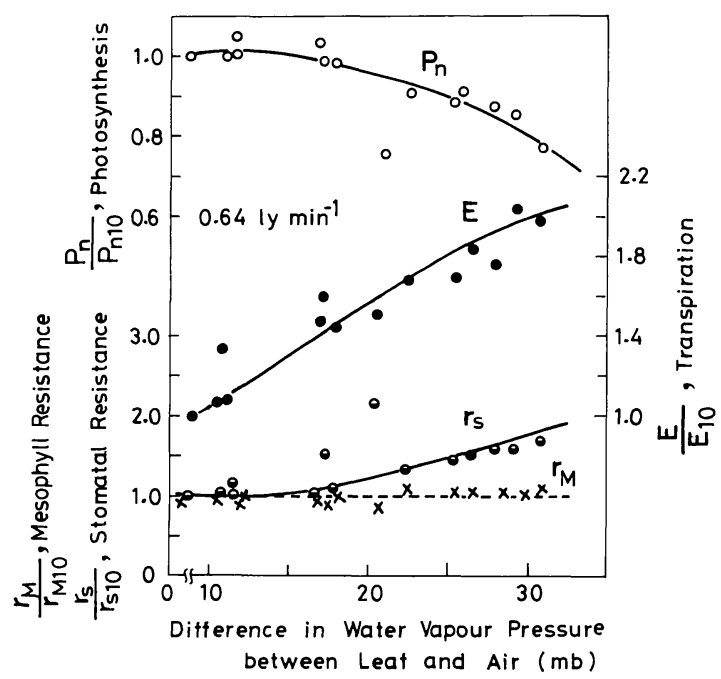

Fig. 2. Dependence on saturation vapour pressure deficit $(V D)$ of relative values of rates of net photosynthesis $\left(P_{n} / P_{n 10}\right)$ and transpiration $\left(E / E_{10}\right)$, and diffusive resistances of stomata $\left(r_{s} / r_{s 10}\right)$ and mesophyll $\left(r_{M} / r_{M 10}\right)$ in rice leaves. The relative values of these quantities are expressed by setting the absolute values at $10 \mathrm{mb} V D$ to unity. synthesis, and $r_{M}$ was unaffected by $V D$.

Ishihara et al. (1971 a and b) measured the degree of stomatal aperture of rice plants under field conditions, and reported that the stomatal aperture reduced at middays with high temperature and radiation intensity and low humidity. Moreover, they found that the depressed stomatal aperture under the conditions of high transpiration demand could be re-opened with a high humidity treatment given by enclosing the plant with a plastic cover. The present results together with those findings by Ishihara et al. lead to the following conclusion. That is, even in rice plants which are growing under paddy field conditions of abundant supply of water, the aerial environments of excessive transpiration demands may cause the depression of the stomatal opening to a considerable degree, which in turn reduces the rate of net photosynthesis to a marked extent.

The generality, that $r_{s}$ increases with the increase in the evaporatory demand as imposed by lowering ambient humidity, is supported by the wide range of plant species (Ludlaw and Wilson, 1971; Schulze et al., 1972; Lange et al., 1971; Hall and Kaufman, 1975; Aston, 1976; Yabuki and Kiyota, 1978). Lange et al. (1971) found that stomata respond to atmospheric humidity directly without the feedback system resulting from lowered leaf water content. This was confirmed also by Aston (1976) with sunflower. With respect to the mechanism with which the stomata respond to the atmospheric humidity, attentions are recently being paid to the peristomatal transpiration (Meidner, 1975; Sheriff and Meidner, 1975; Sheriff, 1977). The peristomatal transpiration is, contrary to classical views, a view that the inner wall of guard and adjacent epidermal cells are the major sites of evaporation from the stomatal transpiration. Moreover, evidences have been reported that water flow through the epidermis exists with a certain degree of isolation or with very high resistance from the remainder of leaf tissue (Sheriff and Meidner, 1974 and Meidner, 1975).

In the present experiment with rice plant, measurements were made with the plants growing in pots with flooding water level, and less than one-third of total leaf area per plant was inserted into the leaf chamber and the remainder leaves were left in the room in which the evaporatory 
demand was very low. Hence, it might have not been the case that the lowering humidity imposed an excessive transpiration than the supply of water to give a reduction in leaf water content. For this reason, it would be more realistic to consider that the stomata of the rice leaves responded directly to the atmospheric humidity, presumably by way of the peristomatal evaporation. To confirm this, however, much effort is needed not only to measure the stomatal resistance but also to measure the leaf water potential at same time.

\subsection{Influence of temperature}

Since the absolute values of $P_{n}, E, r_{s}$ and $r_{M}$ were different among the measurements on different leaves, they were divided by their values at $30^{\circ} \mathrm{C}$ leaf temperature for each series of the measurements at different temperatures, giving relative effects of the leaf temperature on these physiological quantities. In Fig. 3 are given the relative values of the photosynthesis $\left(P_{n}\right)$, the transpiration $(E)$ and also $E / P_{n}$, the transpiration coefficient on a $\mathrm{CO}_{2}$ basis, as a function of the leaf temperature

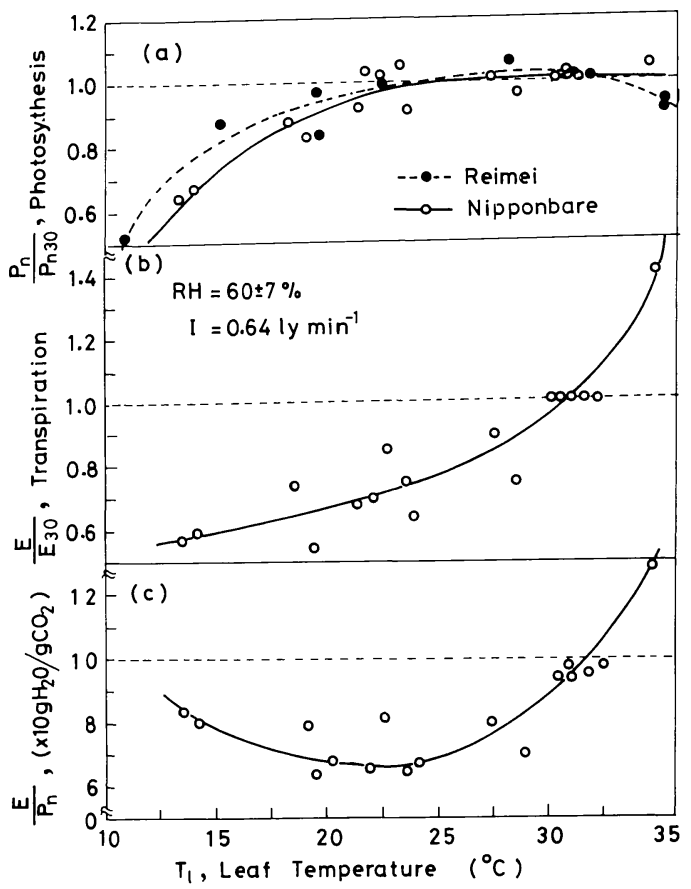

Fig. 3. Dependence on leaf temperature $\left(T_{l}\right)$ of the relative rates of net photosynthesis $\left(P_{n}\right)$ $\left.P_{n 30}\right)$ and transpiration $\left(E / E_{30}\right)$, and transpiration coefficient on a $\mathrm{CO}_{2}$ basis $\left(E / P_{n}\right)$. $P_{n}$ and $E$ are presented as relative values to those at $30^{\circ} \mathrm{C} T_{l}$.
$T_{l}$.

For a comparison, the rate of photosynthesis of a rice cultivar "Reimei", a variety cultivated only at the northern part of Japan is also plotted in Fig. 3, in addition to the variety of "Nipponbare", the main cultivar for this experiment. The optimal range of $T_{l}$ for $P_{n}$ was between $23-32^{\circ} \mathrm{C}$, and below or above this temperature range $P_{n}$ decreased gradually. In comparison with "Nipponbare", "Reimei" showed a tendency of somewhat smaller decline of $P_{n}$ at suboptimal $T_{l}$ and larger decline at superoptimal $T_{l}$. To signify these varietal difference observed here, however, more experimentations are needed. $E$ increased almost exponentially with the increase in $T_{l}$. This is because the saturation water vapour pressure increases with temperature in an exponential fashion. As a consequence of these characteristics of temperature dependence of $P_{n}$ and $E$, the transpiration coefficient $E / P_{n}$ showed a minimum value at around $23^{\circ} \mathrm{C} T_{l}$, and above this temperature it sharply increased, while at temperature below this it showed a tendency of a slight increase with the decrease in $T_{l}$.

To analyse the results given in Fig. 3 based on

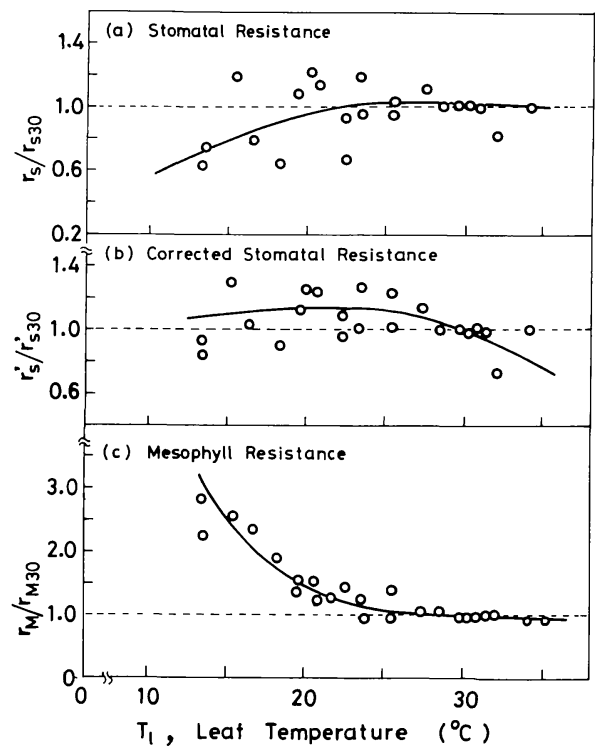

Fig. 4. Dependence on leaf temperature $T_{l}$ of stomatal resistances without $\left(r_{s}\right)$ and with $\left(r_{s}^{\prime}\right)$ correction with the vapour pressure deficit, and mesophyll resistance $\left(r_{M}\right)$ in rice leaves. $r_{s}, r_{s}^{\prime}$ and $r_{M}$ are presented as relative values to those at $30^{\circ} \mathrm{C} T_{l}$. 
gaseous diffusive properties of the leaves, the relative values of the stomatal $\left(r_{s}\right)$ and the mesophyll $\left(r_{M}\right)$ resistances were calculated in the same way as in $P_{n}$ and $E$, and are given in Fig. 4 as a function of the leaf temperature $T_{l}$. Fig. 4-a presents the relative stomatal resistance to that at $30^{\circ} \mathrm{C} T_{l}$ in dependence of $T_{l}$. The average of the absolute values of $r_{s}$ at $30^{\circ} \mathrm{C} T_{l}$ was $1.86 \mathrm{sec} \mathrm{cm}^{-1}$. Although the variation was considerably large, the stomatal resistance showed an increasing tendency with the increase in $T_{l}$. The results shown in Fig. 4-a, however, do not give the effect of $T_{l}$ alone, because increasing temperature, under a constant relative humidity, is necessarily accompanied by the increase in the water vapour pressure difference between leaf and air $(V D)$, of which effect on $r_{s}$ has already been shown in Fig. 2. To exclude the $V D$ effect, the data shown in Fig. 4-a were corrected with $V D$ using the relation between $r_{s}$ and $V D$ given in Fig. 2. Fig. 4-b gives the corrected stomatal resistance $\left(r_{s}^{\prime}\right)$ with $V D$ as a function of $T_{l}$. In this case the average of the absolute values of $r_{s}^{\prime}$ at $30^{\circ} \mathrm{C} T_{l}$ reduced to $1.61 \mathrm{sec} \mathrm{cm}^{-1}$, and the range of the scatter of the points also reduced than that in Fig. 4-a. Moreover, $r_{s}^{\prime}$ even showed a reducing tendency of slight reduction with the increase in $T_{l}$.

The mesophyll resistance $r_{M}$ was fairly constant in the temperature range between 27 and $35^{\circ} \mathrm{C}$, but below this range it increased exponentially with the decrease in $T_{l}$ (Fig. 4-c). The dependence of $r_{M}$ on the leaf temperature $T_{l}$ may be presented by the following equation with satisfactory accuracy:

$$
r_{M}=r_{M, \min }\left\{1+c \exp \left(-k_{m} T_{l}\right)\right\}
$$

in which $r_{M \text {, min }}$ is the minimum $r_{M}$ at the optimal leaf temperature, and $c$ and $k_{m}$ parameters. The values of $r_{M \text {, min }}$ were in the range of $3.6-4.3 \mathrm{sec}$ $\mathrm{cm}^{-1}$ and best estimates for parameters $c$ and $k_{m}$ were 47.8 and 0.233 , respectively. As has already been described, $r_{M}$ is not a purely physical diffusion resistance in the liquid phase, but it also includes the carboxylation resistance related to the biochemical processes of $\mathrm{CO}_{2}$ fixation. It is considered that the dependence of $r_{M}$ on $T_{l}$, shown in Fig. 4-c, was reflecting the temperature effect on the carboxylation resistance more strongly than on the purely physical diffusion resistance.

The exponential decrease in $r_{M}$ with $T_{l}$ does not mean that the photosynthetic rate increases in an exponential fashion with $T_{l}$, because the compensation $\mathrm{CO}_{2}$ concentration $\Gamma$ also increases exponentially (c.f. Fig. 6). The rate of net photosynthesis in relation to $r_{a}, r_{s}, r_{M}$ and $\Gamma$, and also to the external conditions of temperature and humidity is more fully analysed in section 3.4.

Meidner and Mansfield (1968) reviewed the effect of temperature on stomatal aperture and reported that the temperature effect was conflicting among workers. Namely, some workers found that temperature had no effect, some found that stomatal aperture decreased with the increase in temperature and some fou ${ }_{11}$ that it increased with temperature. Meidner and Mansfield gave an explanation to those conflicting results by introducing $\mathrm{CO}_{2}$ factor in the intercellular spaces. It is well known that a high $\mathrm{CO}_{2}$ concentration in the intercellular spaces leads to a closure of stomata. The intercellular space $\mathrm{CO}_{2}$ concentration is closely related to the compensation $\mathrm{CO}_{2}$ concentration in photosynthesis which is known to increase with temperature (Heath and Orchard, 1957; Akita et al., 1969), so that the intercellular space $\mathrm{CO}_{2}$ concentration should also increase with temperature. Thus, according to Meidner and Mansfield, the conflicting results of the temperature effect on $r_{s}$ are derived from difference in the temperature dependence of the compensation $\mathrm{CO}_{2}$ concentration among species.

The present result of analysis on rice leaves may give an another interpretation to the conflicting temperature effects on $r_{s}$. As is shown in Fig. 4-a and $b$, the humidity effect is always coupled with the temperature experiments, unless care is paid to maintain the vapour pressure deficit at a constant level. Hence, it is very likely that the conflicting temperature effects might have been produced by the differences in water vapour pressure deficit $(V D)$ and also by the difference in the sensitivity to $V D$ among species.

\subsection{Influence of soil temperature}

Fig. 5 shows results of soil and water temperature treatments. The underground temperature of a rice plant was stepwise changed from 30 to $10^{\circ} \mathrm{C}$, and then it was increased back to $30^{\circ} \mathrm{C}$. Leaves corresponding to $34 \%$ of the total leaf area of a plant were inserted into the assimilation chamber, and the measurements were made under a constant 


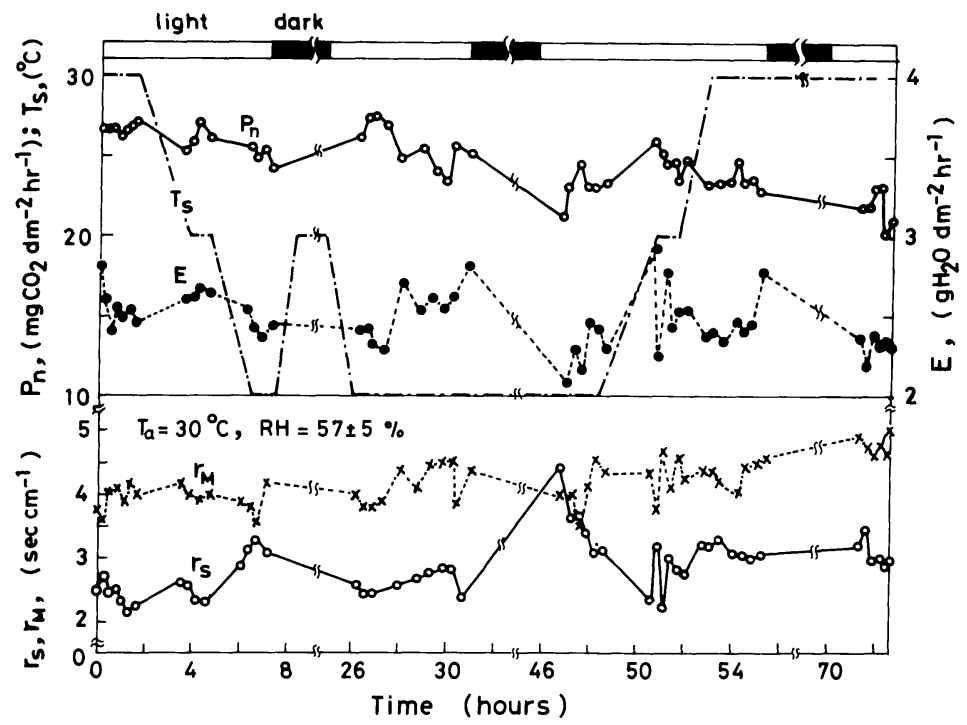

Fig. 5. Changes with under-ground temperature in rates of net photosynthesis $\left(P_{n}\right)$ and transpiration $(E)$, and diffusion resistances of stomata $\left(r_{s}\right)$ and mesophyll $\left(r_{M}\right)$ in rice leaves. The conditions for the measurements were $30^{\circ} \mathrm{C}$ in air temperature and $0.64 \mathrm{cal} \mathrm{cm}^{-2} \mathrm{~min}^{-1}$ in short-wave radiation intensity.

aerial environment of $0.64 \mathrm{cal} \mathrm{cm}^{-2} \mathrm{~min}^{-1}$ in shortwave radiation intensity, $30^{\circ} \mathrm{C}$ in temperature and about $57 \%$ in relative humidity. The remainder leaves, stems and the leaf sheaths were in open air under a weak diffuse room light. The experiment was continued for four days.

With the increase in the duration of the suboptimal temperature treatment at the roots zone, both the rates of $P_{n}$ and $E$ showed a tendency of decline. The decline in these rates was associated with the increase in $r_{s}$, while the mesophyll resistance $\left(r_{M}\right)$ was fairly constant. On the third day of the treatment, in which the root-zone temperature $\left(T_{s}\right)$ was increased back to $30^{\circ} \mathrm{C}$ from continued $10^{\circ} \mathrm{C}$ treatment, $P_{n}$ and $r_{s}$ both did not fully recover to the levels before the suboptimal $T_{s}$ treatment. Namely, the values of $P_{n}$ and $r_{s}$ at $30^{\circ} \mathrm{C}$ $T_{s}$ on the first day were about $26 \mathrm{mgCO}_{2} \mathrm{dm}^{-2} \mathrm{hr}^{-1}$ and $2.5 \mathrm{sec} \mathrm{cm} \mathrm{cm}^{-1}$ respectively, while those values at the same $T_{s}$ on the third day were about $24 \mathrm{mg}$ $\mathrm{CO}_{2} \mathrm{dm}^{-2} \mathrm{~min}^{-1}$ and $3.1 \mathrm{sec} \mathrm{cm}{ }^{-1}$, and hence $8 \%$ reduction in $P_{n}$ and $24 \%$ increase in $r_{s}$ resulted in during the three days' treatment of the suboptimal $T_{s}$. After $T_{s}$ was risen back to $30^{\circ} \mathrm{C}$ the plant was kept under this temperature for one more night, but neither $P_{n}$ nor $r_{s}$ showed any sign of a recovery. Two reasons may be considered for the hysteresis effect of the prolonged $T_{s}$ treatment. One is that after-effect of the suboptimal $T_{s}$ treatment continued for considerably long period. Another is that aging of the leaves was accerelated during the experimental period, because the leaves were kept in the assimilation chamber in unnatural form and environments for four days. Probably, both might be the cause of the hysteresis appeared in $P_{n}$ and $r_{s}$ with the $T_{s}$ treatment.

For the above reasons, difficulties may arise to asses the effects of the suboptimal root-zone temperature on $P_{n}$ and $r_{s}$. However, the ratio of $P_{n}$ and $r_{s}$ at $20^{\circ} \mathrm{C} T_{s}$, measured before the $10^{\circ} \mathrm{C} T_{s}$ treatment, to those at $10^{\circ} \mathrm{C} T_{s}$ may be considered the maximum effect of the low $T_{s}$ treatment, while the ratio of $P_{n}$ and $r_{s}$ at 20 or $30^{\circ} \mathrm{C} T_{s}$, measured after the low $T_{s}$ treatment, to those at $10^{\circ} \mathrm{C}$ may give the minimum effect. The rate of net photosynthesis $\left(P_{n}\right)$ at $20^{\circ} \mathrm{C} T_{s}$ on the first day of the measurement was on average $26.1 \mathrm{mgCO}_{2} \mathrm{dm}^{-2}$ $\mathrm{hr}^{-1}$, the rate at $10^{\circ} \mathrm{C} T_{s}$ on the third day, after the continued 22 hours' treatment of $10^{\circ} \mathrm{C} T_{s}$, was $23.1 \mathrm{mgCO}_{2} \mathrm{dm}^{-2} \mathrm{hr}^{-1}$, and the rate at $20^{\circ} \mathrm{C} T_{s}$ 
just after the $10^{\circ} \mathrm{C} T_{s}$ treatment was $24.8 \mathrm{mgCO}_{2}$ $\mathrm{dm}^{-2} \mathrm{hr}^{-1}$. Hence, the treatment of $10^{\circ} \mathrm{C} T_{s}$ for 22 hours resulted in the reduction of $P_{n}$ on maximum $11 \%$ and on minimum $7 \%$. In the same way as in $P_{n}$, the maximum and the minimum effects of the $10^{\circ} \mathrm{C} T_{s}$ treatment on the stomatal resistance $r_{s}$ was estimated to be 40 and $31 \%$ in comparison with $r_{s}$ at $20^{\circ} \mathrm{C} T_{s}$.

Barlow, Boersma and Young (1977) studied the effect of suboptimal $T_{s}$ on leaf water potential, net photosynthetic rate and transpiration rate in maize seedlings. They found that the leaf water potential decreased with the decrease in $T_{s}$ gradually at first, and at $T_{s}$ below $12.5^{\circ} \mathrm{C}$ it decreased very sharply. With the decrease in $T_{s}, P_{n}$ and $E$ both showed a similar pattern of reduction as the water potential, so that $P_{n}$ at $10^{\circ} \mathrm{C} T_{s}$ reduced to only $20 \%$ of that at $28^{\circ} \mathrm{C}$. Thus, their data clearly indicate that, with the decrease in $T_{s}$, water absorption was suppressed and subsequently a reduction in leaf water potential occurred, which in turn reduced $P_{n}$ and $T_{r}$. An important point in their results is that there exists a critical soil temperature below which the leaf water potential, and hence $P_{n}$ and $E$ both, decrease very sharply.

In the rice plant of this experiment, the reduction in $P_{n}$ as $T_{s}$ decreased from 20 to $10^{\circ} \mathrm{C}$ was only about $10 \%$. This reduction may probably be associated with a reduced rate of water uptake and the subsequent depression in leaf water potential, which in its turn increase the stomatal resistance $r_{s}$. The critical soil temperature as Barlow et al. (1977) found in maize, however, can not be seen in the rice plant, in the range of $T_{s}$ from 30 to $10^{\circ} \mathrm{C}$. If such a critical soil temperature should also exist in rice, it would be lower than $10^{\circ} \mathrm{C}$. To clarify the causes for the difference in the response to low soil temperature between the rice and the maize, more efforts are needed of investigating $T_{s}$ effect in relation to shoot-root ratio and also to the soil water content.

\subsection{Evaluation of interacting effects of air temperature and humidity}

In the foregoing sections, it has been clarified that excessive transpiration demand as imposed by lowering the humidity increases the stomatal resistance $r_{s}$, and hence reduces the rates of net photosynthesis and transpiration in the rice leaves to a marked degree. It was also shown that, in the relation between temperature and these physiological properties of the leaves, the humidity effect is often included. In this section the interacting effects of air temperature and humidity upon $P_{n}$ and $T_{r}$ are numerically evaluated based on the present experimental results.

From eq. (1), the water vapour transfer between the leaves and air may be given by,

$$
\begin{aligned}
E & =2 \frac{\frac{2.17 \times 10^{-4}}{273+T_{l}} e_{s}\left(T_{l}\right)-\frac{2.17 \times 10^{-4}}{273+T_{a}} e_{a}}{r_{a}+r_{s}} \\
& =2 \frac{2.17 \times 10^{-4}}{273+T} \frac{V D}{r_{s}+r_{a}}
\end{aligned}
$$

where $T$ is the average temperature of leaves $\left(T_{l}\right)$ and air $\left(T_{a}\right)$ and $V D$ the difference in the water vapour pressure between the leaves and air. Similarly, the $\mathrm{CO}_{2}$ transfer between the leaves and air is, from eqs. (3) and (4), given by,

$$
P_{n}=\frac{C_{a}-\Gamma}{\frac{1}{2}\left\{r_{a}\left(\frac{D_{H}}{D_{C}}\right)^{2 / 3}+r_{s}\left(\frac{D_{H}}{D_{C}}\right)\right\}+r_{M}}
$$

In equations (6) and (7), the boundary layer resistance $r_{a}$ is a function of wind speed, which function has already been given by eq. (2). Although the stomatal resistance $r_{s}$ showed a slight decline with the increase in the temperature (Fig. 4-b), it is assumed here that $r_{s}$ is independent of the temperature for the sake of simplicity. $r_{s}$ in dependence of the vapour pressure deficit $(V D)$, as shown in Fig. 2, may be presented in the form that:

$$
r_{s}=r_{s 10} f(V D)
$$

in which $r_{s 10}$ is the stomatal resistance at $10 \mathrm{mb}$ $V D$ and is equal to $1.61 \mathrm{sec} \mathrm{cm}{ }^{-1}$, and $f(V D)$ is a factor to give the effect of $V D$ on $r_{s}$ and is shown in Fig. 2. The mesophyll resistance $r_{M}$ has been shown to be independent of $V D$ but strongly dependent on the temperature, and the temperature dependence of $r_{M}$ is given by eq. (5).

The compensation $\mathrm{CO}_{2}$ concentration of photosynthesis $\Gamma$ of the rice leaves is given in Fig. 6 as a function of the leaf temperature $T_{l}$. In Fig. 6 is also cited similar data on rice seedlings reported by Akita, Miyasaka and Murata (1969), although their original data were related to air temperature but not to leaf temperature. In both cases, the 
relation between $\Gamma$ and $T_{l}$ can be presented by the following equation with a satisfactory accuracy:

$$
\Gamma=\Gamma_{30} Q_{10}^{\left(T_{1}-30\right) / 10}
$$

where $\Gamma_{30}$ is the value of $\Gamma$ at $30^{\circ} \mathrm{C}$ and $Q_{10}$ the temperature coefficient. The values of theses parameters, however, were largely different between the present case of the measurements and that by Akita et al. (1969). The estimated values for $\Gamma_{30}$ and $Q_{10}$ in the present case were $48.0 \mathrm{ppm}$ and 1.62 , respectively, while those from the data of Akita et al. were $118 \mathrm{ppm}$ and 2.01, respectively. Two reasons may be considered for the discrepancy in the values of $\Gamma_{30}$ and $Q_{10}$ between the present case of measurements and that by Akita et al.. Firstly, in the latter case $\Gamma$ was related to air temperature but not to the leaf temperature, and it is very usual that the leaf temperature is much higher than the air temperature in assimilation chambers. Secondly, in the former case the measurements were made only on the leaves, while in the latter on whole seedlings, and hence the respiration by heterotrophic organs might be included in the latter. In the simulation the estimated values from the present measurements were used for the parameters $\Gamma_{30}$ and $Q_{10}$.

It is assumed that the leaf temperature is equal to that of air at higher wind speed. Then, equations $(2),(5),(6),(7),(8)$ and (9) suffice to simulate

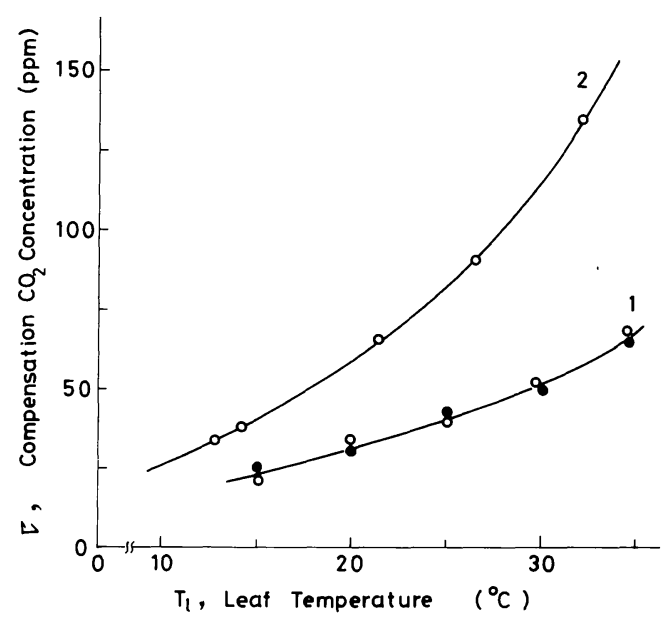

Fig. 6. Temperature dependence of compensation $\mathrm{CO}_{2}$ concentration of photosynthesis $(\Gamma)$ in rice leaves. Curve 1 is derived from the present measurement and 2 from Akita, Miyasaka and Murata (1969).

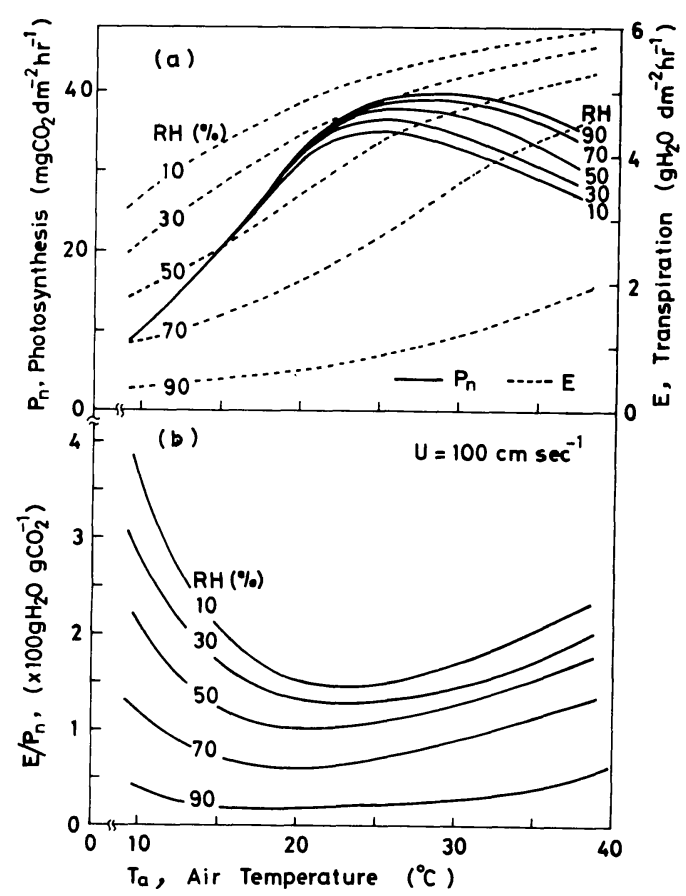

Fig. 7. Simulated rates of net photosynthesis and transpiration, and transpiration coefficient on $\mathrm{CO}_{2}$ basis in dependence of air temperature and humidity.

the rates of net photosynthesis and transpiration at saturating radiation level in relation to air temperature, atmospheric humidity and wind speed. Fig. 7 gives the simulation results for wind speed being $100 \mathrm{~cm} \mathrm{sec}^{-1}$. The results shown in Fig. 7 well illustrate how the atmospheric humidity affects the temperature $\left(T_{a}\right)$-net photosynthesis $\left(P_{n}\right)$ and the $T_{a}$-transpiration $(E)$ relationships. The $T_{a}-E$ relationship should be in a shape of exponential function, if stomatal resistance would not be affected by the vapour pressure deficit $V D$. In Fig. 7, however, such exponential characters can only be seen at higher humidity or at lower $T_{a}$, and at lower humidity or at higher $T_{a}$ the transpiration rate tends to level off. This is because $V D$ increases with the increase in $T_{a}$ or the decrease in the humidity, which in turn increases $r_{s}$.

Fig. 7 also shows that the humidity affects $P_{n}$ at higher temperature to a considerable extent and that the optimal $T_{a}$ for photosynthesis changes with the humidity. In general, the optimum temperature shifts upwards as the humidity increases, and $P_{n}$ at the optimum $T_{l}$ increases with the humidity. These phenomena, appeared in the 
relation among the temperature, the humidity and the net photosynthetic rate, are again due to the $V D$ effect on the stomatal resistance.

As a consequence of the above mentioned characters of $P_{n}$ and $E$, the simulated transpiration coefficient on the $\mathrm{CO}_{2}$ basis in dependence of the temperature and the humidity is as is shown in Fig. 7-b. As has been shown experimentally (Fig. $3)$, the simulated relation between the temperature and the transpiration coefficient is also somewhat concaved curve, with the minimum value around $20^{\circ} \mathrm{C}$. The concaved nature is more apparent at lower humidity. The transpiration coefficient is, of course, higher the lower the humidity.

The above simulation results strongly suggest that a depression in net photosynthetic rate at superoptimal temperature in laboratory or in field may often be accelerated by increased stomatal resistance due to increased vapour pressure deficit. In such situations, it is suggested that the depressed photosynthetic rate at the superoptimal temperature may be recovered, at least partly, by increasing the ambient humidity. It seems worthwhile to examine this possibility by means of experiments.

\section{Acknowledgements}

The author is most thankful to Dr. Z. Uchijima for stimulation to the work, discussion and the improvements of the first draft. He also would like to thank Mr. Sakuratani for some technical supports during the experiments.

\section{Literature Cited}

1) Akita, S., Miyasaka, A. and Murata, Y., 1969: Studies on the difference of photosynthesis among species. I. Difference in the response of photosynthesis among species in normal oxygen concentration as influenced by some environmental factors. Proc. Crop Sci. Soc. Japan, 38, 507-23.

2) Aston, M. J., 1976: Variation of stomatal diffusive resistance with ambient humidity in sunflower (Helianthus annus). Aust. J. Plant Physiol., 3, 489-501.

3) Barlow, E.W.R., Boersma, L. and Young, J.L., 1977: Photosynthesis, transpiration and leaf elongation in corn seedlings at suboptimal soil temperatures. Agron. J., 69, 95-100.

4) Barrs, H. D., 1973: Controlled environment studies of the effects of variable atmospheric water stress on photosynthesis, transpiration and water status of Zea mays L. and other species. In: Plant response to climatic factor (Proc. Uppsala Symp. 1970), pp. 249-58, Slatyer, R. O. ed., Paris, UNESCO.

5) Ehrler, W. L., Nakayama, F. S. and van Bavel, C.H.M., 1965: Cyclic changes in water balance and transpiration of cotton leaves in a steady environment. Physiol. Plant., 18, 766-775.

6) Hall, A.E. and Kaufman, M.R., 1975: Regulation of water transport in the soil-plantatmosphere continum. In: Ecological studies. Analysis and synthesis. (Ed. D. M. Gates and R.B. Schmerl) vol. 12, pp. 187-202. (SpringerVerlag, Berlin).

7) Heath, O. V.S. and Orchard, B., 1957: Temperature effects on the minimum intercellular space carbondioxide concentration. Nature, London, 180, 180-1.

8) Holmgren, P., Jarvis, P. G. and Jarvis, M. S., 1965: Resistance to carbon dioxide and water vapour transfer in leaves of different plant species. Physiol. Plant., 18, 557-73.

9) Horie, T., 1978: Studies on photosynthesis and primary production of rice plants in relation to meteorological environments. 1 . Gaseous diffusive resistances, photosynthesis and transpiration in the leaves as influenced by radiation intensity and wind speed. $J$. Agric. Meteor., Tokyo, 19, 125-136.

10) Ishihara, K., Ishida, Y. and Ogura, T., 1971a: The relationship between environmental factors and behaviour of stomata in the rice plant. 2. On the diurnal movement of the stomata. Proc. Crop Sci. Soc. Japan, 40, 497-504.

11) Ishihara, K., Ishida, Y. and Ogura, T., 1971b: ibid.. 3. On the aperture of the stomata and their diurnal movement in the leaf at different position on the stem. Proc. Crop Sci. Soc. Japan, 40, 505-12.

12) Jarvis, P. G., 1971: The estimation of resistance to carbon dioxide transfer. In: Plant photosynthetic production, manual of methods (Ed. Šesták, Z., Čatský, J. and Jarvis, P. G.), pp. 556-631. Dr. W. Junk N.V. Publishers, The Hague.

13) Meidner, H. and Mansfield, T. A., 1968: Physiology of stomata. 178 pp., McGraw-Hill Book Company, London.

14) Meidner, H., 1975: Water supply, evaporation and vapour difference in leaves. J. Exp. Bot., 26, 666-73.

15) Lange, O. L., Lösch, R., Schulze, E. D. and Kappen, L., 1971: Responses of stomata to changes in humidity. Planta (Berlin), 100, 76-86. 
16) Ludlow, M. M. and Wilson, G. L., 1971: Photosynthesis of tropical pasture plants. I. Illuminance, carbondioxide concentration, leaf temperature, and leaf air vapour pressure difference. Aust. J. Biol. Sci., 24, 449-70.

17) Raschke, K., 1965: Die Stomata als Glieder eines schwingungsfähigen $\mathrm{CO}_{2}$-Regelsystems. Z. Naturforsch., 20b, 1261-70.

18) Rawson, H. M. and Begg, J. E., 1977: The effect of atmospheric humidity on photosynthesis, transpiration and water use efficiency of leaves of several plant species. Planta, 134, 5-10.

19) Sheriff, W. D. and Meidner, H., 1974: Water pathways in leaves of Hedera helix L. and Tradescantia virginiana. J. Exp. Bot., 25, 1147-56.

20) Sheriff, D. W. and Meidner, H., 1975: Water movement into and through Tradescantia viginiana (L.) leaves. I. Uptake during conditions of dynamic equilibrium. J. Exp. Bot., 26, 897-902.

21) Sheriff, D. W., 1977: Evaporation sites and distillation in leaves. Ann. Bot., 41, 1081-82.

22) Shirazi, J. F. and Stone, J. F., 1976: Oscil- latory transpiration in cotton plant. I. Experimental characterization. J. Exp. Bot., 27, 608-18.

23) Slatyer, R. O. and Jarvis, P. G., 1966: Gaseous diffusion porometer for continuous measurement of diffusive resistance of leaves. Science, 151, 574-576.

24) Stålfelt, M. G., 1956: Die stmatäre Transpiration und die Physiologie der Spaltöffnungen. In: Hanbuch der Pflanzenphysiologie, III, 351-426. Springer Verlag, Berlin.

25) Schulze, E. D., Lange, O. L., Buschbom, U., Kappen, L. and Evenari, E., 1972: Stomatal responses to changes in humidity in plant growing in the desert. Planta (Berl.), 108, 259-70.

26) Thom, A. S., 1968: The exchange of momentum, mass, and heat between an artificial leaf and the air flow in a wind-tunnel. Quart. $J$. Roy. Meteorol. Soc., 44, 44-55.

27) Yabuki, K. and Kiyota, M., 1978: Studies on the effects of wind speed on photosynthesis.

(6) The relation between wind speed and diffusive resistance of cucumber leaves. $J$. Agric. Meteor., Tokyo, 34, 59-63.

\section{気象環境とイネの物質生産に関する研究 \\ II . 葉面がス拡散抵抗, 光合成および蒸散 に及ぼす大気湿度と気・水温の影響}

堀江武

（農業技術研究所気象科, 東京都北区西ヶ原 2-1）

要

気象条件からイネの物質生産の動態を説明・予測する シミュレーションモデルを開発することがこの研究の最 終的な目的である。このために必要なデータを得る目的 で, 気孔 $\left(r_{s}\right)$ 挍よび葉肉 $\left(r_{M}\right)$ のガス拡散抵抗, 光合成 および蒸散と大気湿度および気・水温との関係が単葉レ ベルでの同化箱法によってもとめられた。

気温 $30^{\circ} \mathrm{C}$ で相対湿度が $40 \%$ 以下，したがって葉と空 気との間の水蒸気張力差 $(V D)$ が $25 \mathrm{mb}$ 以上で, net の 光合成速度 $P_{n}$, 蒸散速度 $E$ および葉温 $T_{l}$ の振動がみと められた。振動の週期は約 15 分で一定であったが，振 幅は湿度の低下ととあに増大した。これらの振動はすべ て気孔抵抗が振動することによってひき起されたもので あることがわかった。気孔抵抗 $r_{s}$ とVDの関係について みると，VDが $15 \mathrm{mb}$ 以下では $r_{s}$ はほぼ定であったが， $15 \mathrm{mb}$ 以上になると $r_{s}$ は $V D に$ 比例して直線的に増加し

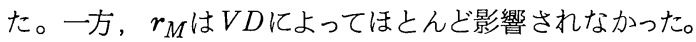

約

このため, 葉と空気間の水蒸気張力差 $V D$ が高くなると 光合成，蒸散と屯にかなりの程度まで抑制された。

相対湿度一定の条件下で葉温を高めた場合，見かけ上 $r_{s}$ は増加した。しかし, この増加は葉温を高めることに 附随するVDの増加によって起ったあのであって, 温度 の直接的な影響とは考えられない。VDの影響を加味し て補正された $r_{s}$ は温度の増加とと屯に逆に減少する傾向 がみられた。一方, 葉肉抵抗 $r_{M}$ は葉温の増加とともに 指数関数的に減少した。 $10^{\circ} \mathrm{C}$ の水・地温処理を連続して 22 時間行なった場合, $20^{\circ} \mathrm{C}$ の場合と比較して $r_{s}$ は 30 〜 40\%増加し, 光合成は 7〜11\%減少した。

以上の実験結果に基づいて, 気温と湿度が $P_{n}$ とEに 与える相互的な影響を評価するための数值計算が行なわ れた。 $P_{n}$ の最適気温は湿度の増加につれて高温側に移 行し, また最適気温条件下における $P_{n}$ は湿度の増加と ともに増大するととが示唆された。 